\title{
Fotoheterotrofni uzgoj ljubičaste nesumporne bakterije Rhodovulum adriaticum na hranjivim podlogama s različitim izvorima ugljika
}

\author{
Photoheterotrophic cultivation of purple non-sulphur bacterium Rhodovulum adriaticum \\ on the media with different carbon sources
}

\author{
Mario Novak ${ }^{1}$, Antonija Trontel ${ }^{1 *}$ Nenad Marđetkoํㅜ, Veronika Matoković1, Marko Sarić1, Mladen Pavlečić1, \\ Božidar Šantek ${ }^{1}$ \\ ${ }^{1}$ Sveučilište u Zagrebu, Prehrambeno - biotehnološki fakultet, Zavod za biokemijsko inženjerstvo, Laboratorij za biokemijsko inženjerstvo, \\ industrijsku mikrobiologiju i tehnologiju slada i piva, Pierottijeva 6/IV, HR-10000 Zagreb, Croatia \\ Centar izvrsnosti Bio Pro Cro - Bioprospecting Jadranskog mora \\ ${ }^{1}$ University of Zagreb, Faculty of Food Technology and Biotechnology, Department of Biochemical Engineering, Laboratory of Biochemical \\ Engineering, Industrial Microbiology, Malting and Brewing Technology, Pierottijeva 6/IV, HR-10000 Zagreb, Croatia \\ Center of Excellence Bio Pro Cro - Marine Bioprospecting
}

*Corresponding author: atrontel@pbf.hr

\section{Sažetak}

Ljubičaste nesumporne bakterije zanimljive su s ekološkog i ekonomskog stajališta u održivim biotehnološkim procesima proizvodnje biogoriva, biokemikalija, biopolimera, biomase odnosno sintezi specifičnih spojeva kao što su npr. karotenoidi i pigmenti. Za uspostavu ekološki i ekonomski održivih bioprocesa nužan je adekavatan odabir radnih mikroorganizama, sirovina i uvjeta kultivacije, a dobar primjer za to je razvoj bioprocesa na obnovljivim sirovinama kao što su to lignocelulozne sirovine. U ovom istraživanju proučavan je fotoheterotrofni uzgoj ljubičaste nesumporne bakterije Rhodovulum adriaticum DSM 2781 na tekućim hranjivim podlogama koje sadrže glukozu i/ili ksilozu kao izvore ugljika s ciljem dobivanja bakterijske biomase i fotosintetskih pigmenata. Rezultati istraživanja pokazuju da su najveće vrijednosti pokazatelja uspješnosti bioprocesa (Y $Y_{X}=$ $2,095 \mathrm{~g} \mathrm{~L}^{-1} ; Y_{X S}=0,54 \mathrm{~g} \mathrm{~g}^{-1}$ i $\left.\mathrm{Pr}=0,022 \mathrm{~g} \mathrm{~L}^{-1} \mathrm{~h}^{-1}\right)$ vezanih u dobivanje biomase ostvareni kod uzgoja na hranjivoj podlozi s $5 \mathrm{~g} L^{-1} \mathrm{glukoze}$. Uzgoj $R$. adriaticum DSM 2781 na hranjivoj podlozi s $3 \mathrm{~g} \mathrm{~L}^{-1}$ glukoze i ksiloze pokazao se najuspješnji za dobivanje fotosintetskih pigmenata (ukupni pigmenti $13,27 \mathrm{mg} \mathrm{g}^{-1}$ biomase) uz zadovoljavajuće ostale pokazatelje uspješnosti bioprocesa $\left(Y_{X}=1,507 \mathrm{~g} \mathrm{~L}^{-1} ; Y_{X / \mathrm{s}}=0,22 \mathrm{~g} \mathrm{~g}^{-1} i \mathrm{Pr}^{2}=0,017 \mathrm{~g} \mathrm{~L}^{-1} \mathrm{~h}^{-1}\right)$.

Ključne riječi: Rhodovulum adriaticum, hranjiva podloga, glukoza, ksiloza, bakterijska biomasa, ukupni fotosintetski pigmenti

\begin{abstract}
Purple non-sulphur bacteria are interesting from ecologic and economic point of view in sustainable biotechnological production of biofuels, biochemicals, biopolymers and biomass as well as specific compounds such as carotenoids and pigments. In order to establish ecological and economic sustainable bioprocesses it is necessary to select adequate working microorganisms, raw materials and cultivation conditions. Development of bioprocesses on the renewable raw materials (e.g. lignocellulose containing feedstocks) are good example for such bioprocess types. In this research, the photoheterotrophic cultivation of purple non-sulfur bacteria Rhodovulum adriaticum DSM 2781 was studied on the liquid media containing glucose or land xylose as a carbon sources in order to produce bacterial biomass and photosynthetic pigments. Results obtained in this study show that the highest values of bioprocess efficiency parameters $\left(Y_{X}=2,095 \mathrm{~g} \mathrm{~L}^{-1} ; Y_{X / S}=0,54 \mathrm{~g} \mathrm{~g}^{-1} i \mathrm{Pr}=0,022 \mathrm{~g} \mathrm{~L}^{-1} h^{-1}\right)$ related to the biomass production were observed during bacterial cultivation on media with $5 \mathrm{~g} \mathrm{~L}^{-1}$. Cultivation of $R$. adriaticum DSM 2781 on the media with $3 \mathrm{~g} \mathrm{~L}^{-1}$ glucose and xylose shows the highest total photosynthetic pigments content $\left(13,27 \mathrm{mg} \mathrm{g}^{-1}\right.$ biomass) together with satisfy other bioprocess efficiency parameters $\left(Y_{X}=1,507 \mathrm{~g} \mathrm{~L}^{-1} ; Y_{X S}=0,22 \mathrm{~g} \mathrm{~g}^{-1} i \mathrm{Pr}=0,017 \mathrm{~g} \mathrm{~L}^{-1} h^{-1}\right)$.
\end{abstract}

Keywords: Rhodovulum adriaticum, cultivation medium, glucose, xylose, bacterial biomass, total photosynthetic pigments

\section{Uvod}

Ljubičaste bakterije su skupina Gram negativnih eubakterija koje čine izrazito raznoliku i heterogenu skupinu široko rasprostranjenih fotosintetskih mikroorganizama u prirodi. Prisutne su u raznim staništima, a mogu se naći u jezerima, ribnjacima, otpadnim vodama, kanalizaciji, obalnim lagunama te ostalim vodenim staništima, kao i u sedimentima, vlažnom tlu i neobrađenim poljima (Imhoff, 2006; Madigan i Jung, 2009; Novak i sur., 2017). Razlika između vrsta i rodova fotosintetskih prokariota obično se bazira na morfološkim karakteristikama kao što su 
veličina i izgled stanice, struktura citoplazmenih membrana i pigmenata, udjelu pojedinih baza u DNA te nekim fiziološkim značajkama poput različite sposobnosti korištenja izvora ugljika i dušika, sposobnosti aerobne i anaerobne respiracije u mraku i slično (Imhoff, 1995; Imhoff i sur., 2005; Madigan i Jung, 2009). Klasifikacija ljubičastih bakterija tradicionalno se povezuje $\mathrm{s}$ metabolizmom sumpora te se podjela na sumporne i nesumporne ljubičaste bakterije najprije zasnivala na različitoj toleranciji i pohranjivanju sumpornih spojeva (Madigan i Jung, 2009). Ljubičaste sumporne bakterije skladište elementarni sumpor unutar stanice, a ljubičaste nesumporne bakterije izvan stanice (Hansen i van Gemerden, 1972). Usporeda na osnovi 16S rRNA sekvenci pokazuje da ljubičaste nesumporne bakterije pripadaju razredima $\alpha$ - i $\beta$-proteobakterija, a ljubičaste sumporne bakterije razredu $\gamma$-proteobakterija (Imhoff i sur., 2005; Imhoff, 2006). Ljubičaste nesumporne bakterije mogu iskorištavati široku paletu izvora ugljika i dušika za potrebe sinteze staničnih komponenata i energije, a putevi razgradnje su opsežni i razlikuju se među vrstama i sojevima unutar istih vrsta (Koku i sur., 2002). Kao faktori rasta, obično su nužni izvori B vitamina poput tiamina, niacina, $\mathrm{p}$ - aminobenzojeve kiseline ili biotina. Također, moguća je upotreba kvaščevog ekstrakta koji sadrži visoki udjel B - vitamina te potiče rast pri manjim koncentracijama (Imhoff, 1995; Madukasi i sur., 2009). Ljubičaste nesumporne bakterije pripadaju skupini anoksigeničnih fotosintetskih prokariota te posjeduju karakteristične fotosintetske pigmente - bakterioklorofile $a$ ili $b$ te karotenoide koji daju specifične boje kolonija u rasponu između ljubičaste, crvene, smeđe i narančaste (Madigan i Jung, 2009; Montano i sur., 2009). Specifični apsorpcijski maksimumi nalaze se u rasponu između 450 i $550 \mathrm{~nm}$ za karotenoide, odnosno između 715 i $1050 \mathrm{~nm}$ za bakterioklorofile (Stomp i sur., 2007; Kuo i sur., 2012). Za sve ljubičaste nesumporne bakterije karakterističan je fotoheterotrofni rast na lako razgradljivim organskim spojevima koji služe kao izvori ugljika i elektrona. Alternativno, moguć je i fotoautotrofni rast uz $\mathrm{CO}_{2}$ kao izvor ugljika te vodikom i manjim koncentracijama reduciranih sumpornih spojeva ili željezovih (II) kationa kao donorima elektrona (Madigan i Jung, 2009). Optimalan $\mathrm{pH}$ u okolišu iznosi 6,5 do 7,0, a odgovaraju im temperature u rasponu od 25 do $35^{\circ} \mathrm{C}$. Također, većina vrsta može tolerirati koncentraciju reduciranih sumpornih spojeva do 0,5 mM u okolini stanice (Madigan i Jung, 2009; Montano i sur., 2009). Tijekom fototrofnog rasta, pridobivanje energije se odvija putem fotosintetske fosforilacije (Lu i sur., 2011). Fotosintetska fosforilacija uključuje apsorpciju fotona u molekulama pigmenata koja rezultira ekscitacijom elektrona i njihovim cirkuliranjem kroz fotosustav. Time dolazi do formiranja transmembranskog gradijenta protona koji predstavlja pokretačku silu za sintezu ATP-a ili redukciju $\mathrm{NADP}^{+}$u NADPH (Ormerod, 1992). U uvjetima limitacije kisikom, osim fototrofnog rasta, određene vrste ljubičastih nesumpornih bakterija poput Rhodobacter capsulatus i Rhodobacter sphaeroides pokazuju sposobnost rasta anaerobnom respiracijom ili fermentacijom u mraku (Imhoff, 2006; Madigan i Jung, 2009; Zannoni i sur., 2009).

Uloga ljubičastih nesumpornih bakterija u suvremenoj biotehnologiji prepoznata je zbog njihove iznimne fiziološke raznolikosti, jednostavnosti prilagodbe na široki raspon uvjeta okoline te sposobnosti biosinteze većeg broja proizvoda $\mathrm{s}$ mogućom komercijalnom primjenom (Imhoff, 2006; Novak i sur., 2017). Uporaba fotosintetskih mikroorganizama općenito se smatra jednom od potencijalnih metoda za smanjenje troškova proizvodnje različitih biotehnoloških proizvoda, a važan je i njihov doprinos u održavanju ekološke ravnoteže zahvaljujući upotrebi solarne energije te sposobnosti fiksacije $\mathrm{CO}_{2}$ i dušika iz atmosfere (Higuchi - Takeuchi i Numata, 2019). Posljednjih godina uvelike se istražuje primjena biomase ljubičastih nesumpornih bakterija u procesima pročišćavanja tla i otpadnih voda iz raznih industrija (Sakpirom i sur., 2017; Sakarika i sur., 2019). Ljubičaste nesumporne bakterije dio su prirodne populacije vlažnih, neobrađenih polja i laguna za obradu otpadnih voda, a njihova prisutnost rezultira biorazgradnjom organskih i anorganskih spojeva te istovremenom biosintezom visokovrijednih nusprodukata (Merugu i sur., 2012). Stanice su bogate proteinima i esencijalnim aminokiselinama, a sposobne su akumulirati značajne količine pigmenata, vitamina i bioloških kofaktora (Vrati, 1984; Novak i sur. 2017). Veći intenzitet istraživanja i razvoj bioprocesa doveli su do otkrivanja različitih proizvoda biomase koju su pronašli svoju primjenu u području medicine, bioenergetike, prehrambene industrije i poljoprivrede. Neki od istaknutijih metaboličkih procesa u stanicama uključuju fotobiološku sintezu vodika i biopolimera, čija važnost posebice leži u tome što predstavljaju alternativu proizvodima koji se trenutno dobivaju iz fosilnih izvora (McKinlay i Hardwood, 2010; Higuchi - Takeuchi i Numata, 2019). Skupinu značajnih proizvoda biomase ljubičastih nesumpornih bakterija čine pigmenti bakterioklorofili i karotenoidi te ostali produkti i međuprodukti njihovih biosintetskih puteva poput 5- aminolevulinske kiseline (5-ALA), vitamina B12, profirina te koenzima $\mathrm{Q}_{10}$ (Sasaki i sur., 1998; Sasaki i sur., 2002; Sasaki i sur., 2005). Bakterijski pigmenti se mogu koristiti kao prirodna bojila za hranu ili tekstil, a imaju i potencijalnu farmakološku ulogu (Numan i sur., 2018). Proizvodnja s većim prinosima se uglavnom postiže tijekom fotoheterotrofnog uzgoja (Patrusheva i sur., 2007). Udjeli bakterioklorofila i karotenoida su obično do $10 \%$ udjela suhe tvari biomase, stoga se smatra prikladno istovremeno dobivanje i ostalih visokovrijednih proizvoda metabolizma (Kobayashi i Kobayashi, 1995; Patrusheva i sur., 2007). Zahvaljujući kontinuiranim istraživanjima, uvođenjem metoda genetičkog inženjerstva te uporabom jeftinih organskih i anorganskih materijala i sirovina, očekuje se daljni razvoj procesa proizvodnje te veća komercijalna primjena stanica ljubičastih nesumpornih bakterija u bliskoj budućnosti.

Fiziologija i potencijal vrste Rhodovulum adriaticum DSM 2781, koja pripada skupini morskih ljubičastih nesumpornih bakterija, nije detaljnije istražena još od prve izolacije i identifikacije vrste 80 -ih godina prošlog stoljeća. Vrsta je izolirana iz Winogradsky kolone, a sadržavala je uzorke blata i vode iz morskog jezera „Malo Jezero“ na otoku Mljetu (Neutzling i sur., 1984). Bakterija Rhodovulum adriaticum DSM 2781 je interesantna, jer može kao izvor ugljika koristiti glukozu, ksilozu i arabinozu (Hiraishi i Ueda, 1994 i 1995) što je važno za biorafinerijski sustav primjene obnovljivih sirovina kao što su lignocelulozne sirovine (Marđetko i sur., 2018). U ovom istraživanju proučavan je fotoheterotrofni uzgoj bakterije Rhodovulum adriaticum DSM 2781 na kemijski definiranim hranjivim podlogama koje su sadržavale glukozu i/ili ksilozu kao izvore ugljika s ciljem dobivanja bakterijske biomase odnosno fotosintetskih pigmenata kao glavnih proizvoda bioprocesa.

\section{Materijali i metode}

\section{Radni mikroorganizam}

$\mathrm{U}$ ovom istraživanju za dobivanje bakterijske biomase odnosno sintezu fotosintetskih pigmenata korištena je ljubičasta nesumporna bakterija Rhodovulum adriaticum DSM 2781 iz DSMZ-German Collection of Microorganisms and Cell Cultures (Braunschweig, Njemačka), a radna kultura se čuva u zbirci mikroorganizama Laboratorija za biokemijsko inženjerstvo, industrijsku mikrobiologiju i tehnologiju slada i piva Prehrambeno-biotehnološkog fakulteta Sveučilišta u Zagrebu.

\section{Hranjive podloge za dobivanje biomase i fotosintetskih pigmenata bakterije Rhodovulum adriaticum DSM 2781}

U ovom istraživanju za potrebe uzgoja bakterije Rhodovulum adriaticum DSM 2781 na različitim izvorima ugljika pripremljene su tekuće hranjive podloge čiji sastav je prikazan u Tablici 1 . Sve kemikalije korištene u ovom istraživanju su bile p.a. čistoće. 
Tablica 1. Osnovni sastav izvora ugljika, dušika, soli i faktora rasta u hranjivim podlogama za pripremu inokuluma, proizvodnju biomase i fotosintetskih pigmenata bakterije $R$. adriaticum DSM 2781.

Table 1. Basic content of carbon and nitrogen sources, salts and growth factors in media for inoculum preparation as well as biomass and photosynthetic pigments production by bacterium R. adriaticum DSM 2781.

\begin{tabular}{|c|c|c|c|c|c|}
\hline $\begin{array}{l}\text { Kemikalija / } \\
\text { Chemicals }\end{array}$ & $\begin{array}{l}\text { Masena koncentracija / } \\
\text { Mass concentration } \\
{\left[\mathrm{g} \mathrm{L}^{-1}\right]}\end{array}$ & $\begin{array}{l}\text { Podloga za uzgoj inokuluma / } \\
\text { Medium for inoculum } \\
\text { preparation } \\
{\left[\mathrm{g} \mathrm{L}^{-1}\right]}\end{array}$ & \multicolumn{3}{|c|}{$\begin{array}{l}\text { Podloge za uzgoj / } \\
\text { Media for cultivations } \\
{\left[\mathrm{g} \mathrm{L}^{-1}\right]}\end{array}$} \\
\hline$\left(\mathrm{NH}_{4}\right)_{2} \mathrm{SO}_{4} \times 7 \mathrm{H}_{2} \mathrm{O}$ & 0,8 & + & + & + & + \\
\hline $\mathrm{KH}_{2} \mathrm{PO}_{4}$ & 0,5 & + & + & + & + \\
\hline $\mathrm{K}_{2} \mathrm{HPO}_{4}$ & 0,5 & + & + & + & + \\
\hline $\mathrm{MgSO}_{4} \times 7 \mathrm{H}_{2} \mathrm{O}$ & 0,2 & + & + & + & + \\
\hline $\mathrm{CaCl}_{2} \times 2 \mathrm{H}_{2} \mathrm{O}$ & 0,053 & + & + & + & + \\
\hline $\mathrm{MnSO}_{4} \times 7 \mathrm{H}_{2} \mathrm{O}$ & $1,2 \times 10^{-3}$ & + & + & + & + \\
\hline Tiamin klorid /Thiamine chloride & $1,0 \times 10^{-3}$ & + & + & + & + \\
\hline Nikotinska kiselina / Nicotinic acid & $1,0 \times 10^{-3}$ & + & + & + & + \\
\hline Biotin/Biotin & $1,0 \times 10^{-5}$ & + & + & + & + \\
\hline $\mathrm{C}_{4} \mathrm{H}_{4} \mathrm{Na}_{2} \mathrm{O}_{5}$ (Na-malat/malate) & 2,7 & + & - & - & - \\
\hline $\mathrm{C}_{6} \mathrm{H}_{12} \mathrm{O}_{6}$ (glukoza/glucose) & 3-15 & - & + & - & + \\
\hline $\mathrm{C}_{5} \mathrm{H}_{10} \mathrm{O}_{5}(\mathrm{ksiloza} / \mathrm{xylose})$ & 3-15 & - & - & + & + \\
\hline Kvaščev ekstrakt / Yeast extract & 1,5 & + & + & + & + \\
\hline $\begin{array}{l}\mathrm{C}_{5} \mathrm{H}_{8} \mathrm{NO}_{4} \mathrm{Na} \\
\text { (Na-glutamat/glutamate) }\end{array}$ & 2,0 & + & + & + & + \\
\hline
\end{tabular}

\section{Priprema hranjivih podloga}

Za uzgoj ljubičaste nesumporne bakterije Rhodovulum adriaticum DSM 2781 koristile su se dvije vrste hranjive podloge. Kemijski definirana hranjiva podloga s malatom kao izvorom ugljika za uzgoj inokuluma (Tablica 1), te kemijski definirana hranjiva podloga s različitim izvorima ugljika (glukoza i/ili ksiloza; Tablica 1). Za pripremu inokuluma odnosno uzgoj bakterijske biomase, hranjiva podloga se priprema tako da se $u$ određeni volumen demineralizirane vode doda izračunata i odvagana masa potrebnih sastojaka hranjive podloge. $\mathrm{pH}$ vrijednost hranjive podloge se korigira na $6,9-7,0$ pomoću $10 \%(\mathrm{~m} / \mathrm{m})$ otopine $\mathrm{NaOH}$, te se podloga sterilizira 20 minuta na $121^{\circ} \mathrm{C}$. Nakon što se hranjiva podloga ohladi, sterilno se dodaju potrebni faktori rasta. Kod hranjivih podloga za uzgoj biomase i sintezu fotosintetskih pigmenata koje sadrže glukozu ili ksilozu kao izvor ugljika, istraživao se utjecaj početne koncentracije izvora ugljika u rasponu od 5 - 15 [g L-1] (Tablica 1). Kod uzgoja bakterije u hranjivim podlogama s glukozom i ksilozom kao izvorima ugljika primjenjene su ove kombinacije jednakih koncentracija izvora ugljika: glukoza i ksiloza 3 [g L${ }^{-1}$ ], glukoza i ksiloza 5 [g L $\mathrm{g}^{-1}$ ] te glukoza i ksiloza 7.5 [g L $\left.{ }^{-1}\right]$ (Tablica 1). Tijekom ovog istraživanja korisni volumen hranjive podloge u Erlenmeyer tikvicama iznosio je $150 \mathrm{~mL}$.

\section{Fotoheterotrofni uzgoj bakterije Rhodovulum adriaticum DSM 2781 u mikroaerofilnim uvjetima na različitim izvorima ugljika}

Uzgoji bakterije Rhodovulum adriaticum DSM 2781 provedeni su u luminostatu pri $2000 \mathrm{Lux}$ - a u mikroaerofilnim uvjetima kroz 96 sati pri temperaturi od $28{ }^{\circ} \mathrm{C}$, bez $\mathrm{pH}$ regulacije i miješanja u Erlenmeyer tikvicama s brušenim čepom. Svaka 24 sata izuziman je uzorak $(5 \mathrm{~mL})$ kojem je određena optička gustoća (staklena kiveta promjera $10 \mathrm{~mm}$ Hellma Optik GmbH, Jena, Njemačka) zbog praćenja rasta bakterijske biomase. Iz dobivene optičke gustoće hranjive podloge pomoću baždarnog pravca $\left(\mathrm{X}=0.7509 \mathrm{~A}_{660}+0.2783 ; \mathrm{R}^{2}=0.9935\right)$ procjenjena je koncentracija suhe tvari bakterijske biomase (X). Osim toga, koncentracija bakterijske biomase praćena je i standardnim određivanjem suhe tvari biomase (Novak i sur., 2017). Za spektrofotometrijska mjerenja tijekom ovog istraživanja korišten je spektrofotometar Cary 100, UV-VIS (Agilent Technologies, Santa Clara, SAD). Potrošnja izvora ugljika tijekom uzgoja $R$. adriaticum DSM 2781 određivana je pomoću tekućinske kromatografije visoke djelotvornosti (HPLC; Shimadzu CLASS-VP LC-10A VP) prema metodi opisanoj u Marđetko i sur. (2018).

\section{Ekstrakcija ukupnih fotosintetskih pigmenata $i$ određivanje njihove koncentracije}

Ekstrakcija ukupnih pigmenata sintetiziranih tijekom uzgoja $R$. adriaticum DSM 2781 provedena je smjesom organskih otapala uz mehaničku dezintergaciju stanica pomoću staklenih kuglica. Uzorak se prethodno centrifugira na $8000 \mathrm{~min}^{-1} \mathrm{kroz} 10$ minuta. U zaostali talog bakterijske biomase dodano je $4 \mathrm{~g}$ staklenih kuglica i $4 \mathrm{~mL}$ smjese acetona i etanola u omjeru 7:2 (vol/vol). Uzorak je naizmjenično podvrgnut intenzivnom miješanju i hlađenju u trajanju od 2 minute $u$ 3 ciklusa intezivnog miješanja odnosno hlađenja. U svrhu sprječavanja raspada fotosenzibilnih pigmenata uslijed izlaganja svjetlosti, postupak ekstrakcije je proveden u mraku, a kivete su bile zaštićene aluminijskom folijom. Nakon provedene ekstrakcije, uzorak je centrifugiran na 8000 $\mathrm{min}^{-1}$ kroz 10 minuta. Spektrofotometrijsko određivanje ukupnih 
pigmenata u supernatantu nakon ekstrakcije odrađeno je u kvarcnoj kiveti promjera $10 \mathrm{~mm}$ (Hellma Optik GmbH, Jena, Njemačka) skeniranjem u području valnih duljina od 350 do $900 \mathrm{~nm}$. Koncentracija ukupnih fotosintetskih pigmenata (UFP; uključivo i bakterioklorofila $a$ ) izračunata je prema izrazu za ekstrakciju primjenom smjese otapala aceton/etanol (Ritchie, 2018):

$$
U F P=0,348209\left(A_{648}-A_{850}\right)-0,16583\left(A_{665}-A_{850}\right)+12,11114\left(A_{775}-A_{850}\right)\left[m g L^{-1}\right]
$$

\section{Određivanje pokazatelja uspješnosti bioprocesa}

Pokazatelji uspješnosti određeni su prema slijedećim jednadžbama:

$$
\begin{gathered}
Y_{X}=X-X_{0}\left[\mathrm{~g} \mathrm{~L}^{-1}\right] \\
Y_{S}=S_{0}-S\left[\mathrm{~g} \mathrm{~L}^{-1}\right] \\
Y_{\frac{X}{S}}=\frac{X-X_{0}}{S_{0}-S}\left[\mathrm{~g} \mathrm{~g}^{-1}\right] \\
Y_{U F P}=\frac{U F P}{X-X_{0}}\left[\mathrm{~g} \mathrm{~g}^{-1}\right] \\
q_{S}=\frac{Y_{S}}{t_{u}}\left[\mathrm{~g} \mathrm{~L}^{-1} \mathrm{~h}^{-1}\right] \\
\operatorname{Pr}=\frac{X-X_{0}}{t_{u}}\left[\mathrm{~g} \mathrm{~L}^{-1} \mathrm{~h}^{-1}\right]
\end{gathered}
$$

Pri čemu je $Y_{X}$ prinos biomase na kraju uzgoja $\left[\mathrm{g} \mathrm{L}^{-1}\right] ; X_{0}$ početna koncentracija biomase $\left[\mathrm{g} \mathrm{L}^{-1}\right] ; X$ konačna koncentracija biomase nakon uzgoja $\left[\mathrm{g} \mathrm{L}^{-1}\right] ; Y_{S}$ ukupna potrošnja supstrata $\left[\mathrm{g} \mathrm{L}^{-1}\right] ; S_{0}$ početna koncentracija supstrata $\left[\mathrm{g} \mathrm{L}^{-1}\right]$; $S$ koncentracija supstrata na kraju uzgoja $\left[\mathrm{g} \mathrm{L}^{-1}\right] ; Y_{X / S}$ koeficijent konverzije suspstrata u biomasu $\left[\mathrm{g} \mathrm{g}^{-1}\right] ; U P F$ koncentracija ukupnih fotosintetskih pigmenata $\left[\mathrm{g} \mathrm{L}^{-1}\right] ; Y_{U P F}$ prinos ukupnih fotosintetskih pigmenata po prirasloj bakterijskoj biomasi [g $\left.\mathrm{g}^{-1}{ }_{\text {biomase }}\right] ; \operatorname{Pr}$ produktivnost rasta biomase $\left[\mathrm{g} \mathrm{L}^{-1} \mathrm{~h}^{-1}\right] ; \mathrm{q}_{\mathrm{s}}$ brzina potrošnje supstrata $\left[\mathrm{g} \mathrm{L}^{-1} \mathrm{~h}^{-1}\right] ; t_{u}$ vrijeme trajanja uzgoja $[\mathrm{h}]$.

\section{Rezultati i rasprava}

Cilj ovog proučavanja bio je odrediti potencijal fotoheterotrofnog uzgoja bakterije $R$. adriaticum DSM 2781 za proizvodnju bakterijske biomase i fotosintetskih pigmenta koji imaju mogućnost primjene za različite svrhe. Biomasa nesumpornih ljubičastih bakterija predstavlja zanimljiv biotehnološki proizvod koji se može koristi kao izvor proteina (Delamare-Deboutteville i sur., 2019), kao radna kultura u procesu bioremedijacije (Sakpirom i sur., 2017), kao biognojivo ili kao izvor fotosintetskih pigmenata i karotenoida (Alloul i sur., 2020). U ovom istraživanju za izvore ugljika odabrani su glukoza i ksiloza zbog toga što obično čine većinski udjel šećera u hidrolizatima lignoceluloznih sirovina (Marđetko i sur., 2018). Primjena sekundarnih lignoceluloznih sirovina u biotehnološkoj proizvodnji je osobito interesantna jer takve sirovine predstavljaju relativno jeftin, lako dostupan i obnovljiv izvor različitih organskih tvari (Choudhury i sur., 2017; Mirza i sur., 2019).

\section{Fotoheterotrofni uzgoj bakterije R. adriaticum DSM 2781 na hranjivim podlogama s glukozom ili ksilozom kao izvorima ugljika}

Rast bakterije $R$. adriaticum DSM 2781 proučavan je na tekućim hranjivim podlogama s glukozom ili ksilozom kao izvorima ugljika $\mathrm{s}$ ciljem dobivanja bakterijske biomase odnosno fotosintetskih pigmenata. Koncentracije glukoze i ksiloze odabrane za uzgoj $R$. adriaticum DSM 2781 predstavljaju uobičajne koncetracije tih šećera koje se mogu dobiti procesom predobrade lignoceluloznih sirovina kao što se npr. pšenična slama, sijeno, kukuruzovina ili kukuruzni oklasci (Marđetko i sur., 2018). Sve ljubičaste nesumporne bakterije karakterizira fotoheterotrofni rast na lako razgradljivim organskim spojevima (npr. šećerima) koji služe kao izvori ugljika i elektrona (Madigan i Jung, 2009; Choudhury i sur., 2017). Centralni metabolizam ugljika za većinu istraženih vrsta ljubičastih nesumpornih bakterija uključuje razgradnju ugljikohidrata Entner - Doudoroff ili Embden - Meyerhof - Parnasovim putem, a daljnju ulogu razgradnje i oksidacije preuzimaju reakcije Krebsovog ciklusa (Tang i sur., 2011; Ormerod, 1992; Tabita, 1995).
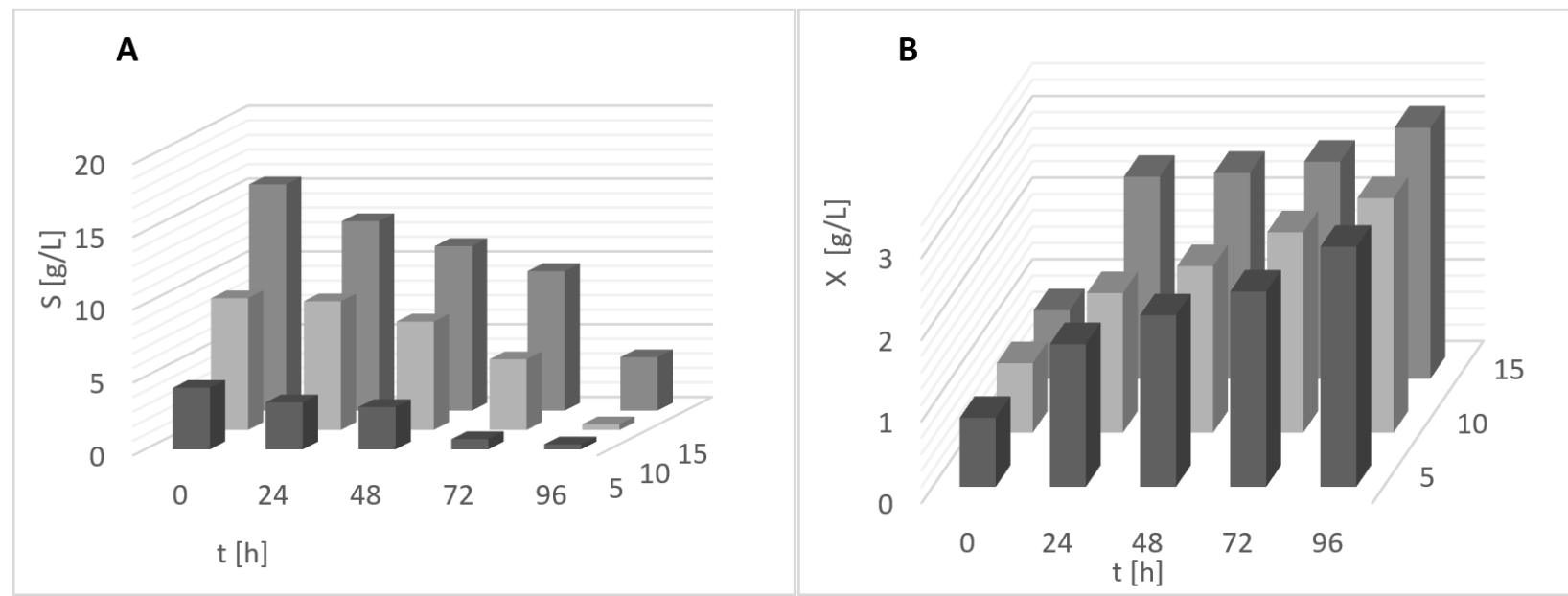

Slika 1. Promjene koncentracije glukoze (A) i bakterijske biomase (B) tijekom uzgoja $R$. adriaticum DSM 2781 na hranjivim podlogama s različitim početnim koncentracijama glukoze ( $\mathrm{S}$ - koncentracija glukoze; $\mathrm{X}$ - koncentracija biomase; $\mathrm{t}$ - vrijeme)

Figure 1. Alteration of glucose (A) and bacterial biomass (B) concentrations during cultivation of R. adriaticum DSM 2781 on media with different initial glucose concentrations ( $S$ - glucose concentration; $X$ - biomass concentration; $t$ - time 

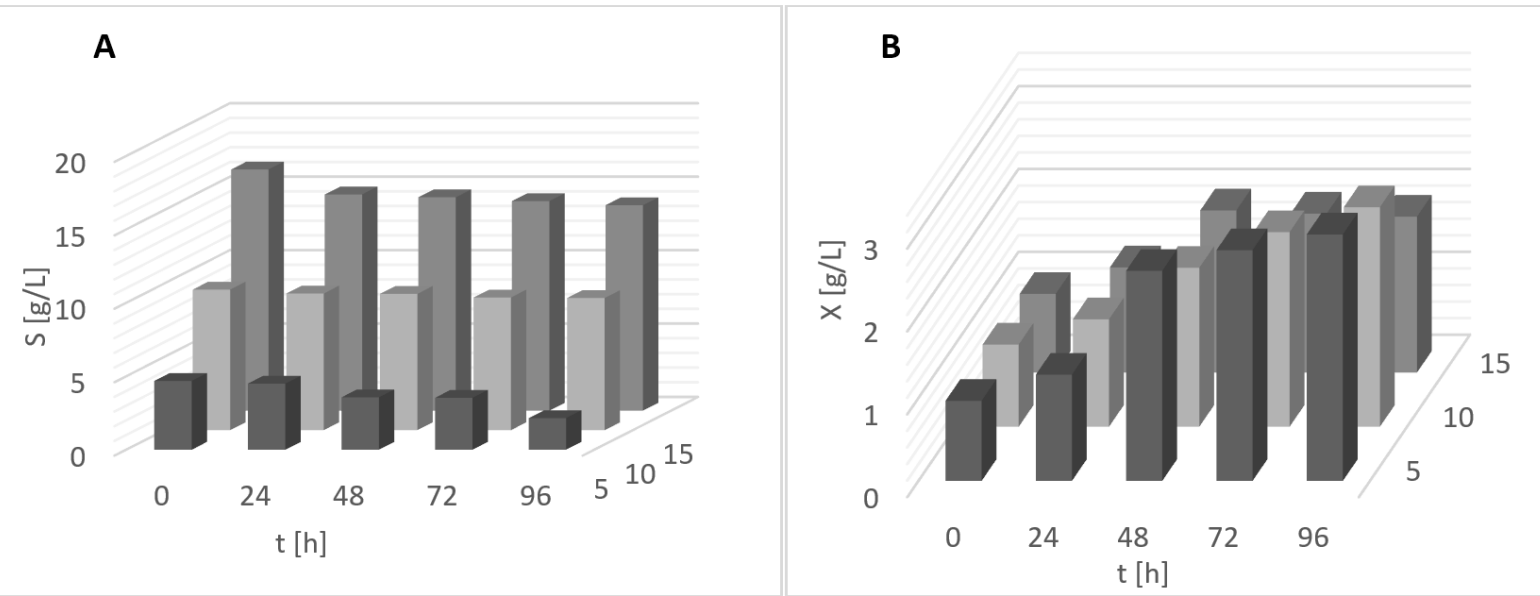

Slika 2. Promjene koncentracije ksiloze (A) i bakterijske biomase (B) tijekom uzgoja $R$. adriaticum DSM 2781 na hranjivim podlogama s različitim početnim koncentracijama ksiloze ( $\mathrm{S}$ - koncentracija ksiloze; $\mathrm{X}$ - koncentracija biomase; $\mathrm{t}$ - vrijeme)

Figure 2. Alteration of xylose (A) and bacterial biomass (B) concentrations during cultivation of R. adriaticum DSM 2781 on media with different initial xylose concentrations ( $S$ - xylose concentration; $X$ - biomass concentration; $t$ - time)

Tijekom uzgoja $R$. adriaticum DSM 2781 na hranjivoj podlozi s $5 \mathrm{~g} \mathrm{~L}^{-1}$ glukoze (Slika 1) utrošilo se $3,879 \mathrm{~g} \mathrm{~L}^{-1}$ glukoze tijekom 96 sati uzgoja, a prinos biomase je iznosio 2,095 $\mathrm{g} \mathrm{L}^{-1}$. Koeficijent konverzije supstrata u biomasu $\left(\mathrm{Y}_{\mathrm{X} / \mathrm{S}}\right)$ bio je $0,54 \mathrm{~g} \mathrm{~g}^{-1}$. Maksimalna brzina potrošnje glukoze registrirana je od 48. do 72. h kultivacije te je iznosila $\mathrm{q}_{\mathrm{S}}=0,040 \mathrm{~g} \mathrm{~L}^{-1} \mathrm{~h}^{-1}$, a ukupna produktivnost bioprocesa bila je $0,022 \mathrm{~g} \mathrm{~L}^{-1} \mathrm{~h}^{-1}$. Kod uzgoja $R$. adriaticum DSM 2781 na hranjivoj podlozi s $5 \mathrm{~g} \mathrm{~L}^{-1}$ ksiloze kao jedinim izvorom ugljika (Slika 2) utrošilo se 2,531 $\mathrm{g} \mathrm{L}^{-1}$ ksiloze tijekom 96 sati uzgoja. Njena maksimalna brzina potrošnje supstrata zabilježena je tek nakon 72 sata $\left(\mathrm{q}_{\mathrm{S}}=0.026 \mathrm{~g} \mathrm{~L}^{-1} \mathrm{~h}^{-1}\right)$ zbog dužeg vremena prilagodbe na ksilozu kao jedini izvor ugljika. Usporedba s uzgojem $R$. adriaticum DSM 2781 na hranjivoj podlozi s glukozom pokazuje da je brzina potrošnje ksiloze bila znatno manja. Prinos biomase je bio približno jednak $(2,008$ $\mathrm{g} \mathrm{L}^{-1}$ ). Kada se koncentracija glukoze u hranjivoj podlozi za uzgoj $R$. adriaticum DSM 2781 poveća s 5 na $10 \mathrm{~g} \mathrm{~L}^{-1}$ prinos biomase se nije značajnije povećao. Međutim, uočeno je $50 \%$ smanjenje koeficijenta $\mathrm{Y}_{\mathrm{X} / \mathrm{S}}=0,23 \mathrm{~g} \mathrm{~g}^{-1}$. Maksimalna brzina potrošnje glukoze uočena je između 72. i 96. h, a iznosila je $0,090 \mathrm{~g} \mathrm{~L}^{-1} \mathrm{~h}^{-1}$. Ukupna produktivnost bioprocesa bila je $0,021 \mathrm{~g} \mathrm{~L}^{-1} \mathrm{~h}^{-1}$. Kada se međusobno usporede uzgoji $R$. adriaticum DSM 2781 na hranjivoj podlozi s glukozom i ksilozom kod $10 \mathrm{~g} \mathrm{~L}^{-1}$ (Slika 2) može se uočiti da je prinos biomase kod uzgoj na ksilozi bio manji za oko $35 \%$ (1,657 $\mathrm{g} \mathrm{L}^{-1}$ uz utrošak ksiloze od 2,983 $\left.\mathrm{g} \mathrm{L}^{-1}\right)$. Ukupna produktivnost bioprocesa je iznosila $0,017 \mathrm{~g} \mathrm{~L}^{-1} \mathrm{~h}^{-1}$. Kod uzgoja $R$. adriaticum DSM 2781 na hranjivoj podlozi s glukozom utrošilo se oko 86 \% izvora ugljika, a kod uzgoja na ksilozi samo $29 \%$ izvora ugljika. Daljnje povećanje koncentracije glukoze ili ksiloze u hranjivoj podlozi na $15 \mathrm{~g} \mathrm{~L}^{-1}$ povezano je $\mathrm{s}$ daljnjim smanjenjem vrijednosti pokazatelja uspješnosti bioprocesa. Tijekom uzgoja $R$. adriaticum DSM 2781 na hranjivoj podlozi s glukozom utrošilo se 79 \% glukoze odnosno samo $16 \%$ ksiloze. Prinos biomase kod uzgoja na hranjivoj podlozi s 15 $\mathrm{g} \mathrm{L}^{-1}$ glukoze bio je 2,236 $\mathrm{g} \mathrm{L}^{-1}$, a koeficijent $\mathrm{Y}_{\mathrm{x} / \mathrm{S}}$ je iznosio $0,19 \mathrm{~g} \mathrm{~g}^{-1}$. Kod uzgoja bakterije na hranjivoj podlozi s ksilozom prinos biomase je bio $0,873 \mathrm{~g} \mathrm{~L}^{-1}$, a koeficijent $\mathrm{Y}_{\mathrm{x} / \mathrm{S}}=0,36 \mathrm{~g} \mathrm{~g}^{-1}$. Na osnovi prethodno navedenog jasno je da povećanje koncentracije supstrata uzrokuje pojavu inhibicije supstratom tijekom fotoheterotrofonog uzgoja $R$. adriaticum DSM 2781 te je stoga neophodno odrediti optimalnu početnu koncentracija supstrata koja ne uzrokuje tu pojavu da bi se ostvarila što veća učinkovitost provođenja bioprocesa.

Biomasa ljubičastih nesumpornih bakterija može se primijeniti u procesima pročišćavanja tla i otpadnih voda iz raznih industrija (Kosakarika i sur., 2019) te koristiti kao izvor proteina i esencijalnih aminokiselina, te raznih spojeva kao što su pigmenti i biološki kofaktori (Novak i sur. 2017). Bakterioklorofili, vitamin B12 i porfirini se proizvode uobičajenim putem sinteze tetrapirola $u$ fotosintetskim bakterijama putem Sheminovog puta biosinteze, pri čemu je početni korak kondenzacija glicina i sukcinata do 5 - ALA (Noparatnaraporn i sur., 1986). Karotenoidi se dobivaju putem sinteze terpenoida, a njihova biosinteza je usko povezana sa sintezom koenzima $\mathrm{Q}_{10}$ (Sasaki i sur., 1998). U ovom istraživanju bakteriofil $a$ i ostali pigmenti određivani su kao ukupni ekstrahirani pigmenti prema Ritchie, 2018. Tijekom određivanja ukupne koncentracije fotosintetskih pigmenata dobivenih uzgojem $R$. adriaticum DSM 2781 na različitim izvorima ugljika uočena su dva karakteristična pika na 800 i $850 \mathrm{~nm}$ koji su apsorpcijski maksimumi bakterioklorofila $a$ (Slika 3). Međutim, dobiveni pikovi nisu specifični samo za ljubičaste nesumporne bakterije već i za druge fotosintetske bakterije koje posjeduju bakterioklorofil $a$, primjerice zelene sumporne bakterije (Sasaki i sur., 2005).
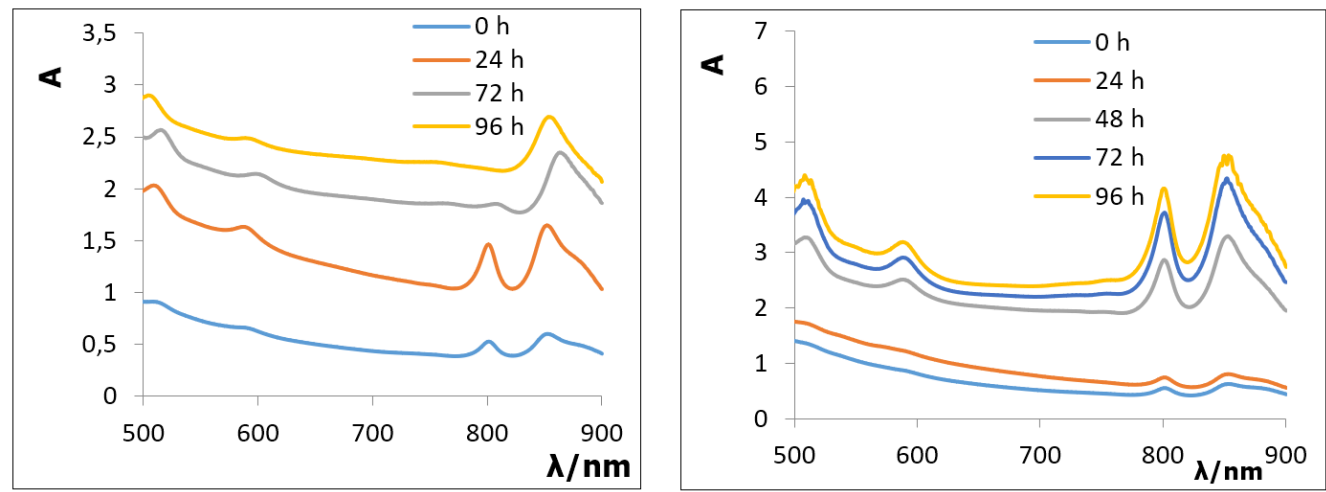

Slika 3. Promjena apsorbancije (A) tijekom uzgoja $R$. adriaticum DSM 2781 na hranjivoj podlozi s glukozom (a) ili ksilozom (b) kao izvorima ugljika

Figure 3. Alteration of absorbance (A) during R. adriaticum DSM 2781 cultivation on media with glucose (a) or xylose (b) as carbon sources 
Ako se glukoza koristi kao jedini izvor ugljika za uzgoj R. adriaticum DSM 2781 koncentracija fotosintetskih pigmenata najčešće pada (Tablica 2) zbog odumiranja biomase ili same autolize fotosintetskih pigmenata. Za nesumporne ljubičaste bakterije specifično je što se same kulture brzo prilagođavaju novim uvjetima i mogu de novo sintetizirati cijeli fotosenzitivni kompleks potreban za fotoheterotrofni rast (Kuo i sur., 2012; Stomp i sur., 2007). Međutim, taj „foto-kompleks“ može se i brzo razgraditi ako uzgoj prelazi iz fotoheterotrofnog u heterotrofni uzgoj (Patrusheva i sur., 2007; Numan i sur., 2018). Kada bakterija raste uz prisustvo svjetlosti i izvora ugljika koji se lako metabolizira (npr. glukoza), vidljiva je potrošnja izvora ugljika u prvoj fazi rasta te povećanje ukupne koncentracije fotosintetskih pigmenata (sinteza bakteriofila a te karotenoida i ostalih pigmenata), a potom $\mathrm{u}$ drugoj fazi dolazi do smanjenja ukupne koncentracije fotosintetskih pigmenata, uz povećanje koncentracije biomase. U ovom istraživanju kod uzgoja R. adriaticum DSM 2781 na hranjivoj podlozi s glukozom također je zabilježena ova pojava (Tablice 2). Najveća koncentracija ukupnih fotosiontetskih pigmenata bila je nakon 48 sati uzgoja, a kod koncentracije glukoze $\mathrm{u}$ hranjivoj podlozi od $5 \mathrm{~g} \mathrm{~L}^{-1}$ iznosila je 7,56 $\mathrm{mg}$ $\mathrm{g}^{-1}$ biomase, kod $10 \mathrm{~g} \mathrm{~L}^{-1}$ glukoze $8,04 \mathrm{mg} \mathrm{g}^{-1}$ biomase. Međutim, kod koncetracije glukoze od $15 \mathrm{~g} \mathrm{~L}^{-1}$ došlo je do smanjenja koncentracije fotosintetskih pigmenata na $3,32 \mathrm{mg} \mathrm{g}^{-1}$ biomase zbog pojave inhibicije supstratom rasta bakterije R. adriaticum DSM 2781 (Tablica 2). Za razliku od uzgoja R. adriaticum DSM 2781 na hranjivoj podlozi s glukozom kod uzgoja na hranjivoj podlozi s ksilozom zabilježena je suprotna pojava tj. koncentracija ukupnih fotosintetskih pigmenata raste tijekom uzgoja i najveća je na kraju bioprocesa (96 h; Tablica 3). Najveća koncentracija ukupnih fotosintetskih pigmenata zabilježena je kod koncentracije ksiloze $\mathrm{u}$ hranjivoj podlozi od $10 \mathrm{~g} \mathrm{~L}^{-1}\left(6,54 \mathrm{mg} \mathrm{g}^{-1}\right.$ biomase), kod $5 \mathrm{~g} \mathrm{~L}^{-1} \mathrm{ksiloze}$ iznosila je $5,23 \mathrm{mg} \mathrm{g}^{-1}$ biomase, a najmanja je kod koncentracije ksiloze od $15 \mathrm{~g} \mathrm{~L}^{-1}\left(2,29 \mathrm{mg} \mathrm{g}^{-1}\right.$ biomase; Tablica 3). Smanjanje ukupne koncentracije fotosintetskih pigmenata kod $15 \mathrm{~g}$ $\mathrm{L}^{-1} \mathrm{ksiloze} u$ hranjivoj podlozi posljedica je pojave inhibicije supstratom gdje zbog usporenog rasta bakterijske biomase dolazi i do smanjene sinteze fotosintetskih pigmenata biomase (Choudhury i sur., 2017). Budući da ksiloza nije povoljan izvor ugljika za rast i dobivanje energije kod R. adriaticum DSM 2781 (Slika 2; Hiraishi i Ueda, 1994 i 1995; Choudhury i sur., 2017) potreban je dulji vremenski period za sintezu fotosenzitivnog kompleksa pri čemu se odvija i sinteza fotosintetskih pigmenata čija koncentracija se time dodatno povećava u odnosu na uzgoj s glukozom kao izvorom ugljika.

Tablica 2. Koncentracija ukupnih pigmenata tijekom uzgoja bakterije $R$. adriaticum DSM 2781 na hranjivim podlogama s glukozom kao izvorom ugljika

Table 2. Total pigment concentration during cultivation of R. adriaticum DSM 2781 on cultivation media with glucose as a sole carbon source

\begin{tabular}{|l|l|l|l|l|}
\hline Hranjiva podloga/ Medium & $\begin{array}{l}\text { Ukupni pigmenti / Total } \\
\text { pigments - 48h } \\
{\left[\mathrm{mg} \mathrm{L}^{-1}\right]}\end{array}$ & $\begin{array}{l}\text { Ukupni pigmenti / Total } \\
\text { pigments - 48h } \\
{\left[\mathrm{mg} \mathrm{g}_{\text {biomasa }}^{-1}\right]}\end{array}$ & $\begin{array}{l}\text { Ukupni pigmenti / Total } \\
\text { pigments - 96h } \\
{\left[\mathrm{mg} \mathrm{L}^{-1}\right]}\end{array}$ & $\begin{array}{l}\text { Ukupni pigmenti / Total } \\
\text { pigments - 96h } \\
{\left[\mathrm{mg} \mathrm{g}_{\text {biomasa }}^{-1}\right]}\end{array}$ \\
\hline Glukoza/ Glucose $5 \mathrm{~g} \mathrm{~L}^{-1}$ & 15,65 & 7,56 & 6,73 & 2,29 \\
\hline Glukoza/ Glucose $10 \mathrm{~g} \mathrm{~L}^{-1}$ & 16,74 & 8,04 & 6,54 & 2,27 \\
\hline Glukoza / Glucose $15 \mathrm{~g} \mathrm{~L}^{-1}$ & 8,52 & 3,32 & 6,77 & 2,20 \\
\hline
\end{tabular}

Tablica 3. Koncentracija ukupnih pigmenata tijekom uzgoja bakterije $R$. adriaticum DSM 2781 na hranjivim podlogama s ksilozom kao izvorom ugljika

Table 3. Total pigment concentration during cultivation of R. adriaticum DSM 2781 on cultivation media with xylose as a sole carbon source

\begin{tabular}{|l|l|l|l|l|}
\hline Hranjiva podloga/ Medium & $\begin{array}{l}\text { Ukupni pigmenti / Total } \\
\text { pigments - 48h } \\
{\left[\mathrm{mg} \mathrm{L}^{-1}\right]}\end{array}$ & $\begin{array}{l}\text { Ukupni pigmenti / Total } \\
\text { pigments - 48h } \\
{\left[\mathrm{mg} \mathrm{g}_{\text {biomasa }}^{-1}\right]}\end{array}$ & $\begin{array}{l}\text { Ukupni pigmenti / Total Ukupni pigmenti / Total } \\
\text { pigments - 96h } \\
{\left[\mathrm{mg} \mathrm{L}^{-1}\right]}\end{array}$ & $\begin{array}{l}\text { pigments - 96h } \\
{\left[\mathrm{mg} \mathrm{g}_{\text {biomasa }}^{-1}\right]}\end{array}$ \\
\hline Ksiloza/Xylose $5 \mathrm{~g} \mathrm{~L}^{-1}$ & 9,58 & 3,77 & 15,55 & 5,22 \\
\hline Ksiloza/Xylose $10 \mathrm{~g} \mathrm{~L}^{-1}$ & 4,12 & 2,14 & 17,33 & 6,54 \\
\hline Ksiloza/Xylose $15 \mathrm{~g} \mathrm{~L}^{-1}$ & 2,76 & 1,41 & 4,31 & 2,29 \\
\hline
\end{tabular}

\section{Fotoheterotrofni uzgoj bakterije R. adriaticum DSM 2781 na hranjivim podlogama s glukozom i ksilozom kao izvorima ugljika}

Uzgoj $R$. adriaticum DSM 2781 na hranjivim podlogama sa samo jednim izvorom ugljika pokazao je da bakterija može rasti na glukozi ili ksilozi kao jedinim izvorima ugljika, ali da joj je rast usporen zbog inhibicije supstratom kod koncentracija izvora ugljika većih od $10 \mathrm{~g} \mathrm{~L}^{-1}$ (Slike 1 i 2). Veća koncentracija ukupnih fotosintetskih pigmenata zabilježena je kod uzgoja na hranjivoj podlozi s ksilozom usmjerila je istraživanje prema primjeni oba izvora ugljika u hranjivoj podlozi s ciljem dobivanja što većeg prinosa bakterijske biomase odnosno ukupnih fotosintetskih pigmenata kao što su bakteriofila $a$, karotenoidi i ostali pigmenti. 


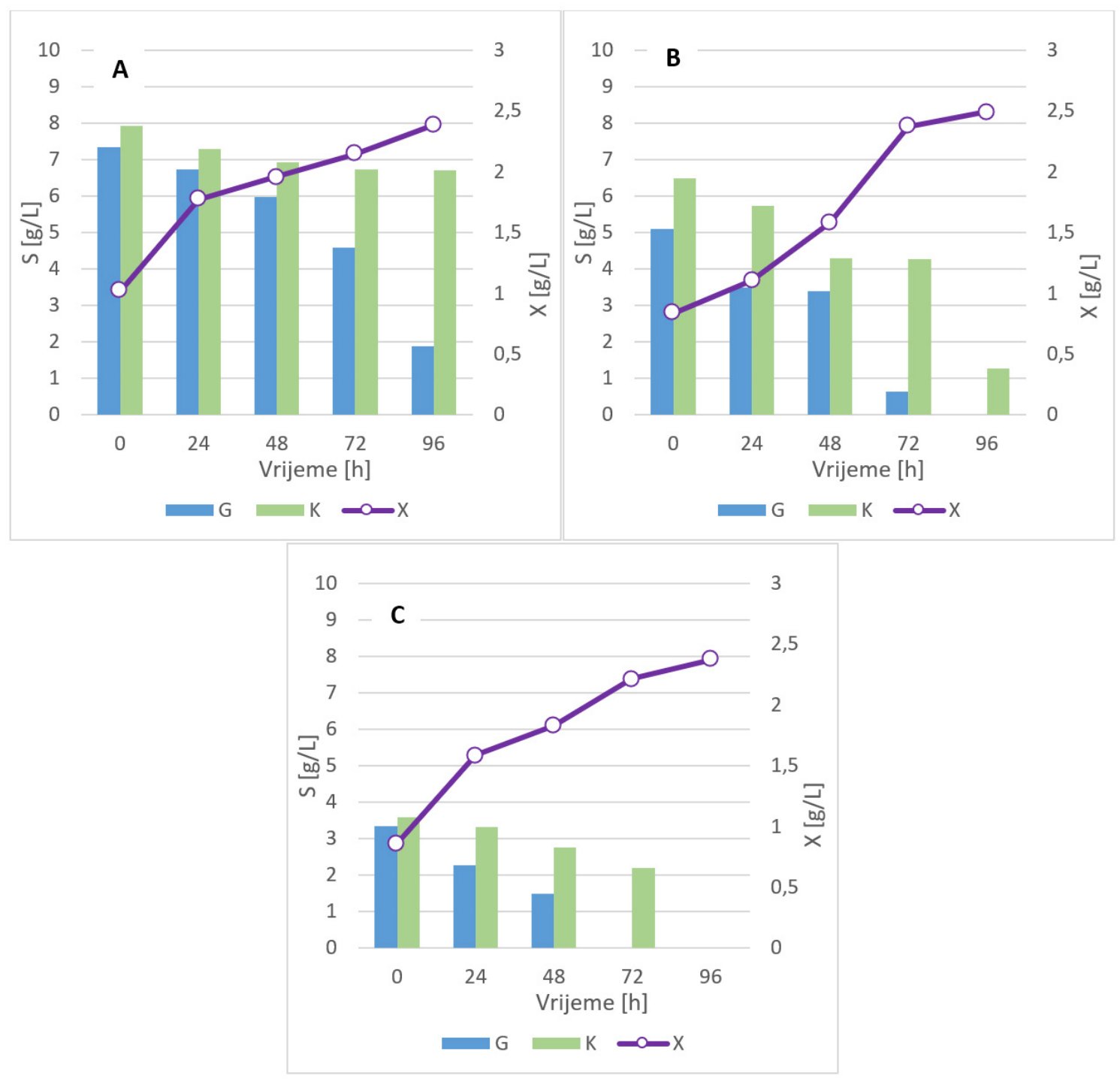

Slika 4. Promjene koncentracije izvora ugljika i bakterijske biomase tijekom uzgoja $R$. adriaticum DSM 2781 na hranjivim podlogama s jednakim koncentracijama glukoze i ksiloze: $3 \mathrm{~g} \mathrm{~L}^{-1}$ (A); $5 \mathrm{~g} \mathrm{~L}^{-1}$ (B) i $7.5 \mathrm{~g} \mathrm{~L}^{-1}$ (C) (S - koncentracija supstrata; G - koncentracija glukoze; K - koncentracija ksiloze; X - koncentracija biomase; t - vrijeme)

Figure 4. Changes of carbon sources and bacterial biomass concentrations during cultivation of R. adriaticum DSM 2781 on media with equal glucose and xylose concentrations: $3 \mathrm{~g} \mathrm{~L} L^{-1}(A) ; 5 g L^{-1}(B) i 7.5 g L^{-1}(C)$ (S - substrate concentration; $G$ - glucose concentration; $K$ - xylose concentration; X - biomass concentration; $t$ - time)

U ovom dijelu istraživanja koncentracije pojedinih šećera odabrane su tako da budu manje od $10 \mathrm{~g} \mathrm{~L}^{-1}$ jer je tijekom uzgoja na koncentracijama pojedinim izvora ugljika od $10 \mathrm{~g} \mathrm{~L}^{-1}$ i većim oučena inhibicija supstratom odnosno smanjenje prinos biomase i fotosintetskih pigmenata (Slike 1. i 2.). Zbog toga su odabrane ove tri kombinacije jednakih koncentracija izvora ugljika (glukoze i ksiloze) u hranjivoj podlozi: $3 \mathrm{~g} \mathrm{~L}^{-1}, 5 \mathrm{~g} \mathrm{~L}^{-1} \mathrm{i}$ $7,5 \mathrm{~g} \mathrm{~L}^{-1}$. Rezultati ovog dijela istraživanja prikazani su na Slici 4 . Iz prikazanih rezultata je vidljivo da su glukoza i ksiloza tijekom uzgoja $R$. adriaticum DSM 2781 na hranjivoj podlozi s $3 \mathrm{~g} \mathrm{~L}^{-1}$ oba šećera potpuno utrošena u periodu od 96 sati. Usporedba $\mathrm{s}$ uzgojem $R$. adriaticum DSM 2781 na samo jednom izvoru ugljika (Slike 1 i 2) pokazuje veću pojedinačnu potrošnju supstrata što je najvjerojatnije posljedica potrošnje supstrata za prilagodbu bakterije na promjenu izvora ugljika tijekom uzgoja, ali i za energiju održavanja bakterije u tim uvjetima (Sasaki i sur., 2005). U prethodno navedenom uzgoju prinos biomase je iznosio $1,507 \mathrm{~g} \mathrm{~L}^{-1}$, a koeficijent $\mathrm{Y}_{\mathrm{X} / \mathrm{s}} 0,22 \mathrm{~g} \mathrm{~g}^{-1}$ što je oko $50 \%$ manje nego kod uzgoja na hranjivoj podlozi sa samo jednim izvorom ugljika. Navedeno smanjenje koeficijenta $Y_{\mathrm{x} / \mathrm{S}}$ posljedica je potrošnje supstrata na energiju održavanja i prilagodbu metablizma na različite izvore ugljike (Sasaki i sur., 2005). Ukupna produktivnost bioprocesa je iznosila $0,017 \mathrm{~g} \mathrm{~L}^{-1} \mathrm{~h}^{-1}$.
Kod uzgoja $R$. adriaticum DSM 2781 na hranjivoj podlozi s početnom koncentracijom glukoze i ksiloze od $5 \mathrm{~g} \mathrm{~L}^{-1}$, došlo je do potpune potrošnje glukoze te $81 \%$ potrošnje ksiloze. Prinos biomase $R$. adriaticum DSM 2781 je bio oko $10 \%$ veći nego kod uzgoja na hranjivoj podlozi s $3 \mathrm{~g}$ $\mathrm{L}^{-1}$ oba izvora ugljika. Ukupna produktivnost bioprocesa $\left(0,018 \mathrm{~g} \mathrm{~L}^{-1} \mathrm{~h}^{-1}\right)$ bila je na približno istoj razini kao i kod uzgoja na hranjivoj podlozi s 3 $\mathrm{g} \mathrm{L}^{-1}$ oba izvora ugljika. Povećanjem početne koncentracije oba izvora ugljika u hranjivoj podlozi dolazi do inhibicije rasta supstratom te je utrošeno samo $72 \%$ glukoze odnosno $15 \%$ ksiloze. Prinos biomase je bio manji u odnosu na uzgoje $R$. adriaticum DSM 2781 manjih početnih koncentracijama oba izvora ugljika. Koeficijent $\mathrm{Y}_{\mathrm{X} / \mathrm{S}}$ je bio na približno istoj razini kao i kod uzgoja na hranjivoj podlozi s $3 \mathrm{~g} \mathrm{~L}^{-1}$ oba izvora ugljika $\left(0,21 \mathrm{~g} \mathrm{~g}^{-1}\right)$. Na osnovi rezultata ovog dijela istraživanja vidljivo je da $R$. adriaticum DSM 2781 bolje raste na hranjivim podlogama samo sa jednim izvorom ugljika te bi za dobivanje bakterijske biomase trebalo koristi hranjive podloge s jednim izvorom ugljika (npr. glukoza) vodeći računa o mogućnostima primjene tog izvora ugljika $\mathrm{u}$ industrijskom mjerilu.

Određivanje ukupnih fotosintetskih pigmenata kod uzgoja $R$. adriaticum DSM 2781 na hranjivim podlogama s oba izvora ugljika uočavaju se 
također karakteristični pikovi na 800 i $850 \mathrm{~nm}$ koji u apsorpcijskom spektru odgovaraju bakterioklorofila $a$ (Ritchie, 2018). Kod svih uzgoja $R$. adriaticum DSM 2781 na hranjivoj podlozi s oba izvora ugljika najveća koncentracija ukupnih fotosintetskih pigmenata (uključujući i bakteriofila a) zabilježena je nakon 48 sati uzgoja, a prema kraju bioprocesa se smanjuje (Tablica 4). Najveće koncentracije ukupnih fotosintetskih pigmenata registrirane su kod uzgoja $R$. adriaticum DSM 2781 na hranjivoj podlozi s $3 \mathrm{~g} \mathrm{~L}^{-1}$ glukoze i ksiloze $\left(13,27 \mathrm{mg} \mathrm{g}^{-1}\right.$ biomase), a čak $88 \%$ manje koncentracije su određene kod uzgoja na hranjivoj podlozi s 7,5 $\mathrm{g} \mathrm{L}^{-1}$ glukoze i ksiloze (1,66 $\mathrm{mg} \mathrm{g}^{-1}$ biomase). Kod uzgoja $R$. adriaticum DSM 2781 na hranjivoj podlozi s $5 \mathrm{~g} \mathrm{~L}^{-1}$ glukoze i ksiloze detektirano je $6,45 \mathrm{mg} \mathrm{g}^{-1}$ biomase ukupnih fotosintetskih pigmenata. Usporedba s uzgojem $R$. adriaticum DSM 2781 na hranjivim podlogama sa samo jednim izvorom ugljika pokazuje približno jednake koncentracije ukupnih fotosintetskih pigmenata, a izuzetak je uzgoj na hranjivoj podlozi s $3 \mathrm{~g} \mathrm{~L}^{-1}$ glukuze i ksiloze gdje su zabilježene najveće koncentracije fotosintetskih pigmenata. Ova pojava pokazuje da prisustvo ksiloze u malim koncentracijama stimulara sintezu fotosintetskih pigmenata. Međutim, potrebno je provesti dodatna istraživanja i odrediti optimalnu koncentraciju ksiloze koja imam pozitivan učinak na sintezu fotosinteski pigmenata.

Tablica 4. Promjene koncentracije ukupnih pigmenata tijekom uzgoja bakterije R. adriaticum DSM 2781 na hranjivim podlogama s glukozom i ksilozom kao izvorima ugljika

Table 4. Alteration of total pigment concentration during cultivation of R. adriaticum DSM 2781 on media with glucose and xylose as carbon sources

\begin{tabular}{|c|c|c|c|c|}
\hline Hranjiva podloga/ Medium & $\begin{array}{l}\text { Ukupni pigmenti / Total } \\
\text { pigments - } 48 \mathrm{~h} \\
{\left[\mathrm{mg} \mathrm{L}^{-1}\right]}\end{array}$ & $\begin{array}{l}\text { Ukupni pigmenti / Total } \\
\text { pigments - } 48 \mathrm{~h} \\
{\left[\mathrm{mg} \mathrm{g}_{\text {biomasa }}^{-1}\right]}\end{array}$ & $\begin{array}{l}\text { Ukupni pigmenti / Total } \\
\text { pigments - } 96 \mathrm{~h} \\
{\left[\mathrm{mg} \mathrm{L}^{-1}\right]}\end{array}$ & $\begin{array}{l}\text { Ukupni pigmenti / Total } \\
\text { pigments - } 96 \mathrm{~h} \\
{\left[\mathrm{mg} \mathrm{g}_{\text {biomasa }}{ }^{-1}\right]}\end{array}$ \\
\hline $\begin{array}{l}3 \mathrm{~g} \mathrm{~L}^{-1} \text { Glukoza i } 3 \mathrm{~g} \mathrm{~L}^{-1} \mathrm{ksiloza} / 3 \mathrm{~g} \mathrm{~L}^{-1} \\
\text { Glucose and } 3 \mathrm{~g} \mathrm{~L}^{-1} \text { Xylose }\end{array}$ & 24,21 & 13,27 & 4,26 & 1,80 \\
\hline $\begin{array}{l}5 \mathrm{~g} \mathrm{~L}^{-1} \text { Glukoza i } 5 \mathrm{~g} \mathrm{~L}^{-1} \text { Ksiloza / } 5 \mathrm{~g} \\
\mathrm{~L}^{-1} \text { Glucose and } 5 \mathrm{~g} \mathrm{~L}^{-1} \text { Xylose }\end{array}$ & 10,14 & 6,45 & 2,31 & 0,92 \\
\hline $\begin{array}{l}\text { 7,5 } \mathrm{g} \mathrm{L}^{-1} \text { Glukoza i 7,5 } \mathrm{g} \mathrm{L}^{-1} \text { Ksiloza / } \\
\text { 7,5 } \mathrm{g} \mathrm{L}^{-1} \text { Glucose and 7,5 } \mathrm{g} \mathrm{L}^{-1} \text { Xylose }\end{array}$ & 3,25 & 1,66 & 3,81 & 1,60 \\
\hline
\end{tabular}

\section{Zaključci}

Ljubičaste nesumporne bakterije imaju važnu ulogu u suvremenoj biotehnologiji zahvaljujući njihovoj iznimnoj fiziološkoj raznolikosti i prilagodljivosti na široki raspon uvjeta okoline. Njihova sposobnost sinteze značajnog broja visokovrijednih proizvoda $\mathrm{s}$ primjenom $\mathrm{u}$ području medicine, bioenergetike te prehrambene industrije $\mathrm{i}$ poljoprivrede daje im važnu ulogu u tzv. biorafinerijskom pristupu (Imhoff, 2006; Novak i sur., 2017). Glukoza i ksiloza su interesentan izvor ugljika ako se dobivaju iz obnovljivih sirovina poput slame, sijena, kukurozovine ili kukuruznih oklaska (Marđetko i sur., 2018; Mirza i sur., 2019). U ovom istraživanju glukoza i ksiloza su odabrane kao izvori ugljika jer obično čine većinski udjel šećera u hidrolizatima lignoceluloznih sirovina (Marđetko i sur., 2018). Rezultati istraživanje pokazuju da je kod uzgoja $R$. adriaticum DSM 2781 na hranjivoj podlozi s $5 \mathrm{~g} \mathrm{~L}^{-1}$ glukoze zabilježen najveći koeficijent pretvorbe supstrata $\mathrm{u}$ biomasu $\left(\mathrm{Y}_{\mathrm{X} / \mathrm{S}}\right)$ od $0,54 \mathrm{~g} \mathrm{~g}^{-1}$. Povećanje koncentracije glukoze $(10-15 \mathrm{~g}$ $\left.\mathrm{L}^{-1}\right)$ u hranjivoj podlozi povezano je sa smanjenjem koeficijenta $Y_{X / S}(10$ $\mathrm{g} \mathrm{L}^{-1}=0,23 \mathrm{~g} \mathrm{~g}^{-1}$ i $15 \mathrm{~g} \mathrm{~L}^{-1}=0,19 \mathrm{~g} \mathrm{~g}^{-1}$ ) zbog inhibicije supstratom. Kod uzgoja $R$. adriaticum DSM 2781 na hranjivoj podlozi s većim početnim koncentracijama ksiloze inhibicija supstratom je bila još izraženija te su stoga pokazatelji uspješnosti $\left(Y_{X}, Y_{X / S}\right.$ i $\left.P r\right)$ bili oko $50 \%$ manji u odnosu na uzgoj kod $5 \mathrm{~g} \mathrm{~L}^{-1}$ ksiloze. Kod uzgoja $R$. adriaticum DSM 2781 na hranjivoj podlozi s jednakim koncentracijama oba izvora ugljika (glukoza i ksiloza) najveće vrijednosti pokazatelja uspješnosti bioprocesa zabilježene su kod $5 \mathrm{~g} \mathrm{~L}^{-1}\left(Y_{X}=1,65 \mathrm{~g} \mathrm{~L}^{-1} ; Y_{X S}=0,22 \mathrm{~g} \mathrm{~g}^{-1}\right.$ i $P r=0,018 \mathrm{~g}$ $\left.\mathrm{L}^{-1} \mathrm{~h}^{-1}\right)$. Veće koncentracije oba izvora ugljika inhibiraju rast bakterije $R$. adriaticum DSM 2781. Koncentracija ukupnih fotosintetskih pigmenata (uključujući i bakteriofila $a$ ) najveća je nakon 48 sati uzgoja (izuzetak je hranjiva podloga s ksilozom gdje registrirana kod 96 h) $R$. adriaticum DSM 2781 kod većine uzgoja provedenih u ovom istraživanju. Za sintezu fotosintetskih pigmenata najpogodnija je hranjiva podloga $s$ jednakom koncentracijom glukoze i ksiloze od $3 \mathrm{~g} \mathrm{~L}^{-1}$. Daljnje povećanje koncentracije oba izvora ugljika u hranjivoj podlozi vezano je uz pojavu inhibicije supstratom rasta $R$. adriaticum DSM 2781 zbog čega dolazi i do smanjenja sinteze fotosintetskih pigmenata.

\section{Zahvale:}

Ovaj rad je financiran u sklopu znanstveno - istraživačkih projekata „Bioprospecting Jadranskog mora BioProCro“ (KK.01.1.1.01.0002) i „Održiva proizvodnja biokemikalija iz sekundarnih lignoceluloznih sirovina“" (HRZZ-9717).

\section{Literatura}

Alloul A., Cerruti M., Adamczyk D., Weissbrodt D. G., Vlaeminck S. R. (2020) Control Tools to Selectively Produce Purple Bacteria for Microbial Protein in Raceway Reactors. bioRxiv 2020.01.20.912980.

Choudhury D., Saini S. (2017) Sugar Co-utilization in Microorganismsm. U: Gunasekaran, P., Noronha, S., Pandey, A., (ed) Current Developments in Biotechnology and Bioengineering. Funcional Genomics and Metabolic Engineering, str. 243-268. Elsevier, Netherlands

Correa D. F., Beyer H. L., Fargione J. E., Hill J. D., Possingham H. P., Thomas-Hall S. R., Schenk P. M. (2019) Towards the Implementation of Sustainable Biofuel Production Systems. Renewable and Sustainable Energy Reviews, 107250 - 263.

Delamare-Deboutteville J., Batstone D.J., Kawasaki M., Stegman S., Salini M., Tabrett S., Smullen R., Barnes A.C., Hülsen T. (2019) Mixed Culture Purple Phototrophic Bacteria is an Effective Fishmeal Replacement in Aquaculture. Water Research X, 4100031.

Hansen T. A., van Gemerden H. (1972) Sulfide Utilization by Purple Nonsulfur Bacteria. Archives of Microbiology, 8649 - 56. 
Higuchi - Takeuchi M., Numata K. (2019) Marine Purple Photosynthetic Bacteria as Sustainable Microbial Production Hosts. Frontiers in Bioengineering and Biotechnology, 7258.

Hiraishi A., Ueda Y. (1994) Intrageneric Structure of the Genus Rhodobacter: Transfer of Rhodobacter sulfidophilus and related marine species to the genus Rhodovulum gen. nov. International Journal of Systematic Bacteriology, 44 (1) 15 - 23.

Hiraishi A., Ueda Y. (1995) Isolation and characterization of Rhodovulum strictum sp. nov. and some other purple nonsulfur bacteria from colored blooms in tidal and seawater pools. International Journal of Systematic Bacteriology, 45 (2) 319 - 326.

Imhoff J. F. (1995) Taxonomy and Physiology of Phototrophic Purple Bacteria and Green Sulfur Bacteria. U: Blankenship, R. E., Madigan, Michael T., Bauer, C. E., (ed) Anoxygenic Photosynthetic Bacteria, str. 6 - 8, Kluwer Academic Publishers, Netherlands,

Imhoff J. F. (2006) The Phototrophic Alpha - Proteobacteria. U: Dworkin M., Falkow S., Rosenberg E., Schleifer KH., Stackebrandt E., (ed.) The Prokaryotes, vol. 5: Proteobacteria: Alpha and Beta Subclasses, str. 41 - 64, Springer, New York

Imhoff J. F., Hiraishi A., Süling J.(2005) Anoxygenic Phototrophic Purple Bacteria. U: Brenner, D. J., Krieg, N. R., Staley, J. T., Garrity, G. M., (ed.) Bergey's Manual ${ }^{\circledR}$ of Systematic Bacteriology, str. 119 - 132, Springer, Boston, MA

Kobayashi M., Kobayashi M. (1995) Waste Remediation and Treatment Using Anoxygenic Phototrophic Bacteria. U: Blakenship, R. E., Madigan, M. T., Bauer, C. E., (ed.) Anoxygenic Photosynthetic Bacteria. Advances in Photosynthesis and Respiration vol 2, str. 1269 - 1282. Springer, Dordrecht Koku H., Eroğlu I., Gündüz U., Yücel M., Türker L. (2002) Aspects of the Metabolism of Hydrogen Production by Rhodobacter sphaeroides. International Journal of Hydrogen Energy, 271315 - 1329.

Kuo F. S., Chien Y. H., Chen C. J. (2012) Effects of Light Sources on Growth and Carotenoid Content of Photosynthetic Bacteria Rhodopseudomonas palustris. Bioresource Technology, $113315-318$.

Lu H., Zhang G., Dong S. (2011) Quantitative Study of PNSB Energy Metabolism in Degrading Pollutants Under Weak Light-Micro Oxygen Condition. Bioresource Technology, 102 (8) $4968-4973$.

Madigan M. T., Jung D. O. (2009) An overview of Purple Bacteria: Systematics, Physiology, and Habitats. U: Neil Hunter, C., Daldal, F., Thurnauer, M. C., Beatty, J. T., (ed.) The Purple Phototrophic Bacteria, str. 1 - 15, Springer, Dordrecht

Madukasi E. I., Dai X., He C., Zhou J. (2009) Potentials of Phototrophic Bacteria in Treating Pharmaceutical Wastewater. International Journal of Environmental Science and Technology, 7 (1) 165 - 174.

Marđetko N., Novak M., Trontel A., Grubišić M., Galić M., Šantek B. (2018) Bioethanol Production from Dilute-acid Pre-treated Wheat Straw Liquor Hydrolysate by Genetically Engineered Saccharomyces cerevisiae. Chemical and Biochemical Engineering Quarterly, 32 (4) 483 - 499.

McKinlay J. B., Harwood C. S. (2010) Photobiological Production of Hydrogen Gas as a Biofuel. Current Opinion in Biotechnology, 21 (3) 244 - 251. Merugu R., Rudra M. P. P., Girisham S., Reddy S. M. (2012) Biotechnological Applications of Purple Non Sulphur Phototrophic Bacteria: A Minireview. International Journal of Applied Biology and Pharmaceutical Technology, 3 (1) 376 - 384.

Montano G. L., Chan J. S., Jarabelo R. E., Pastor A. B. I., Dela Cruz T. E. E. (2009) Isolation and Characterization of Purple Nonsulfur Bacteria (PNSB) from a Rice Paddy Soil in Bulacan, Philippines. Philippine journal of systematic biology, 3 (1) 57 - 67.

Neutzling O., Imhoff J. F., Trüper H. G. (1984) Rhodopseudomonas adriatica sp. nov., a new species of the Rhodospirillaceae, dependent on reduced sulfur compounds. Archives of Microbiology, $137256-261$.

Novak M., Pavlečić M., Harutyunyan B., Goginyan V., Horvat P., Šantek B. (2017) Characteristics and Selection of Cultures of Photosynthetic Purple Non-Sulphur Bacteria as a Potential 5-Aminolevulinic Acid Producers. Croatian Journal of Food Technology, Biotechnology and Nutrition, 12 (3-4) $113-119$.

Numan M., Bashir S., Mumtaz R., Tayyab S., Rehman N. U., Khan A. L., Shinwari Z. K., Al-Harrasi A. (2018) Therapeutic Applications of Bacterial Pigments: a Review of Current Status and Future Opportunities. 3 Biotech, 8207.

Ormerod J. G. (1992) Physiology of the Photosynthetic Prokaryotes. U: Mann, N. H., Carr, N. G., (ed.) Photosynthetic Prokaryotes. Biotechnology Handbooks vol 6, str. 93 - 120. Springer, Boston, MA

Patrusheva E. V., Fedorov A. S., Belera V. V., Minkevich I. G., Tsygankov A. A. (2007) Synthesis of Bacteriochlorophyll $a$ by the Purple Nonsulfur Bacterium Rhodobacter capsulatus. Applied Biochemistry and Microbiology, 8 (7) 187 - 192.

Ritchie R. J. (2018) Measurement of Chlorophylls $a$ and $b$ and Bacteriochlorophyll $a$ in Organisms From Hypereutrophic Auxinic Waters. Journal of Applied Phycology, 30 (6) 3075 - 3087.

Sakarika M., Spanoghe J., Sui Y., Wambacq E., Grunert O., Haesaert G., Spiller M., Vlaeminck S. S. (2019) Purple non-sulphur bacteria and plant production: benefits for fertilization, stress resistance and the environment. Microbial Biotechnology, 13 (5) 1336 - 1365.

Sakpirom J., Kantachote D., Nunkaew T., Khan E. (2017) Characterizations of Purple Non-Sulfur Bacteria Isolated from Paddy Fields, and Identification of Strains with Potential for Plant Growth-Promotion, Greenhouse Gas Mitigation and Heavy Metal Bioremediation. Research in Microbiology, 168 (3) $266-275$.

Sasaki K., Tanaka T., Nagai S. (1998) Use of Photosynthetic Bacteria for the Production of SCP and Chemicals from Organic Wastes. U: Martin, A. M., (ed.) Bioconversion of Waste Materials to Industrial Products, str. 247 - 292. Springer, Boston, MA, str.

Sasaki K., Watanabe M., Suda Y., Ishizuka A., Noparatnaraporn N. (2005) Applications of Photosynthetic Bacteria for Medical Fields. Journal of Bioscience and Bioengineering, 100 (5) $481-488$.

Sasaki K., Watanabe M., Tanaka T., Tanaka T. (2002) Biosynthesis, Biotechnological Production and Applications of 5-Aminolevulinic acid. Applied Microbiology and Biotechnology, 58 (1) $23-29$.

Stomp M., Huisman J., Stal L. J., Matthijs H. C. P. (2007) Colorful Niches of Phototrophic Microorganisms Shaped by Vibrations of the Water Molecule. The ISME Journal, 1271 - 282.

Tabita F. R. (1995) The Biochemistry and Metabolic Regulation of Carbon Metabolism and Fixation in Purple Bacteria Redox Balance and Carbon Metabolism Central Pathways for Organic Carbon Metabolism. U: Blankenship, R. E., Madigan, Michael T., Bauer, C. E., (ed.) Anoxygenic Photosynthetic Bacteria, str. 885 - 914, Kluwer Academic Publishers, Netherlands

Tang K. H., Tang Y. J., Blankenship R. E. (2011) Carbon metabolic pathways in phototrophic bacteria and their broader evolutionary implications. Frontiers in Microbiology, $21-23$.

Vrati S. (1984) Single Cell Protein Production by Photosynthetic Bacteria Grown on the Clarified Effluents of Biogas Plant. Applied Microbiology and Biotechnology, 19 (3) $199-202$.

Zannoni D., Schoepp-Cothenet B., Hosler J. (2009) Respiration and Respiratory Complexes. U: Hunter, C. N., Daldal, F., Thurnauer, M. C., Beatty, J. T., (ed.) The Purple Phototrophic Bacteria. Advances in Photosynthesis and Respiration vol 28, str. 537-561. Springer, Dordrecht 